\title{
THE TIGER WAITING ON THE SHORE
}

\author{
Days of remembrance.
}

\section{BY PAUL CURRION}

$\mathrm{I}$ am sitting in front of a man folded up like newspaper. His breath rustles in his bed sheets. His fluids are visible beneath his skin. The plastic pipe is more robust than the vein it feeds. I can hear so many things, including my own eyes blinking. I am looking at my son.

We have nothing to say to each other. At least, I have nothing to say to him, and he can't say anything at all. The last time I saw him, he was 14 years old, sitting on the other side of a perspex panel, and crying without control because I was about to be deep-sixed.

Now he is 94, and the only perspex panel between us is the passage of time. In 10 minutes, the prison guards will come and take me back to my bedroom. It's comfortable enough - more comfortable than this medical cell - but I won't be spending much time there.

This is the second day of my prison sentence. On the first day, I was woken by the guard and taken to my husband's wedding. I watched as he successfully moved on with his life without me. On the third day of my prison sentence, everybody I knew will be dead, and I will be released.

I accept my responsibility: involuntary manslaughter is still manslaughter. The family of the man I killed held a public vote, and the public spoke. The public is squeamish now - or at least, it was squeamish then, all those years ago - and so my punishment was humane.

Yet this is a hell. It's a hell that barely scratches the skin, true, a hell that puts me mercifully out of sight, but it is a hell that is merciless in its means. It is the afternoon of the second day of my prison sentence, and my punishment has barely begun.

I think for a moment about whether I should take my chances when the guards

$\rightarrow$ NATURE.COM

Follow Futures:

@ @NatureFutures

f go.nature.com $/ \mathrm{mtoodm}$ return; but death by cop is not an option any more, not with the next generation of non-lethal weapons, and who knows what advances they've made in the decades since I was sent away? Better not to risk it.

On the other hand, what more could they do to me? Let's imagine I managed to overpower the guards, escape the hospice, lose myself in the street somehow. I have no idea what the world looks like now, I have no idea

the squeamish, not then, but the alternative was far worse. That first night, I slept for a decade: the second night, 70 years; my third and final night may last 100 more; and I will know every second of that century.

I will be unawake, my body slowed by drugs, but my mind stretched over time as if it was on the rack. I will have 100 years to reflect on what I did, and what the consequences were, and my one memory will be of this: my own son, dying.

He shuffles himself into a different position, every card in his pack faded and creased. His mouth works like the mouth of a furious little animal that lives beneath the earth, thin and pale and cracked. He knows that I am here. He is trying to speak.

I lean forward so that I can hear him. These might be his last words. They will be his last words to me. "I found the family —" he starts to say, and then stops, and then, "- the man you killed." When he opens his eyes, the light of 80 years past shines

what language they speak, or anything else considered common.

No. I will go back to my bedroom, and go to sleep and wake up tomorrow, 100 years from now. I will pick up the package that all prisoners receive, and be released into a population of my peers. Criminals, like me. Exiles, like me. We will be housed, and fed, and cared for.

We won't be required to wear bracelets or chains. We will live our lives in some resource-constrained recreation of the society that put us to sleep, quarantined from whatever society we wake into. That future society may not want us, but I hope that they will be... humane.

When the result of the vote to decide my fate was announced, my husband - who began the process of successfully moving on at that very moment - tried to explain to my son that it wasn't so bad, that it could be worse, that I could have received the death penalty.

My son saw the truth that my husband could not see. Death was not for again for me.

"It makes no difference," I tell him gently. "They think that this is punishment, but seeing you before you died - this is something I wanted." I reach for him - a breach of protocol - and he rubs his fingers against the back of my hand.

"They tried to reverse the decision," he tells me, and we laugh together. The very idea, of turning back time! Of putting the genie back in the bottle, of bringing back the dead! Time runs like a river for him, and crawls like a glacier for me - but still, it goes in one direction only.

Everybody knows that the past is a foreign country, but so is the future. I have been sent far away with no chance ever to return. Tomorrow I will wake, washed up on the shore of a brave new world, where I will stagger to my feet, and press on into the forest, to face whatever tigers await.

Paul Currion is his own worst pseudonym. (More reliable information can be found at www.currion.net). 